\title{
DCC wt Allele
}

National Cancer Institute

\section{Source}

National Cancer Institute. DCC wt Allele. NCI Thesaurus. Code C54427.

Human DCC wild-type allele is located in the vicinity of $18 q 21.3$ and is approximately 1190 $\mathrm{kb}$ in length. This allele, which encodes netrin receptor DCC protein, plays a role in both axonal guidance and neuronal growth cone formation. Mutation of this gene may be associated with both colorectal and esophageal carcinomas. 